\title{
ESTIMATION OF COMBINING ABILITY AND HETEROTIC POTENTIAL FOR WITHIN-BOLL YIELD TRAITS UNDER LEAF CURLING DISEASE INFESTATION IN COTTON
}

\author{
Amir SHAKEEL $L^{1}$, Muhammad Mansoor SHERAZ ${ }^{1}$, Asif SAEED ${ }^{1}$, Imtiaz $_{\text {ALI }}{ }^{*}$, \\ Wajad NAZEER ${ }^{3}$, Zahid AMIN ${ }^{1}$, Ali AMMAR ${ }^{2}$ \\ ${ }^{1}$ University of Agriculture, Department of Plant Breeding and Genetics, Faisalabad, PAKISTAN \\ ${ }^{2}$ Regional Agricultural Research Institute, Bahawalpur, PAKISTAN \\ ${ }^{3}$ Muhammad Nawaz Shareef University of Agriculture, Multan, PAKISTAN \\ *Corresponding author: imtiaz.malghani@gmail.com
}

Received: 22.04 .2015

\begin{abstract}
Cotton leaf curling disease $(\mathrm{CLCuD})$ is the major threat to cotton production and quality in many cotton producing countries including Pakistan. The objective of current work was to identify the potential genotypes which perform well under the disease prevalence through manipulating the within-boll yield traits. For this purpose; six genotypes possessing broad genetic base were selected and crossed in all possible combinations. Crossed seeds from 30 combinations and selfed seeds from 6 parental genotypes, thus produced, were grown along with parents under field conditions in randomized complete block design replicated thrice. Analysis of variance depicted significant differences among genotypes for all the traits under consideration. Strong evidences for the prevalence of non-additive genetic behavior of the traits were recorded. The genotype MNH886 was found as good general combiner for lint mass per boll, seed mass per seed and CLCuD index; MNH888 for lint mass per seed and seed cotton yield while VH-61 for seed mass per boll and seed number per boll. Results pertaining to specific combining ability effects revealed that the most desirable combinations for various traits were; FH-113 $\times$ FH-2015 for lint mass per boll and seed number per boll, MNH-888 $\times$ IR-4 for lint percentage and lint mass per seed, MNH-888 $\times$ VH-61 for seed cotton yield and CLCuD index. Most of the hybrids showed greater mid parent heterosis than that of better parent. Results from the current study supported the hypothesis that seed cotton yield and quality can be enhanced through exploitation of withinboll yield components in CLCuD tolerant cultivars.
\end{abstract}

Key words: Bt-cotton, CLCuD, combining ability, heterosis, within-boll yield components.

\section{INTRODUCTION}

Cotton is a major fiber and oil seed crop in many tropical areas of the world and a major cash crop of Pakistan (Iqbal et al., 2011). About $80 \%$ of the cotton area in the world is under the two tetraploid species i.e. $G$. hirsutum and G. barbadense (Imran et al., 2012). Cotton shares $7 \%$ of value added to agriculture and $1.5 \%$ in GDP of Pakistan (Anonymous, 2012-13). A production of about 13 million bales was obtained from 2.88- million hectares during the year 2012-13 (Anonymous, 2012-13) which was $4.2 \%$ less than produced in 2011-12. Cotton productivity on unit land area basis, in Pakistan, is low as compared to many leading cotton producing countries of the world (Ali et al., 2015). Not only is the yield, fiber quality is also low in most of the locally developed upland cotton cultivars when compared with rest of the world cotton producers.

Both food security and the general agricultural crops are under the threat of major biotic and abiotic factors
(Farooq et al., 2011). Cotton genotypes are under the severe biotic constraint of cotton leaf curling disease i.e. CLCuD (Akhtar et al., 2005). CLCuD, a whitefly (Bemisia tabaci Genn) transmitted Gemini virus is well known for causing major disasters to cotton production in Pakistan (Yassin and El-Nour, 1970; Mansoor et al., 1993; Hameed et al., 1994; Akhtar et al., 2002). The disease is characterized by upward curling of leaves and/or leaf veins are thickened on the underside of leaves. In medium to high intensity of the disease, plants are stunted, producing less and small sized boll with inferior lint quality (Farooq et al., 2011). In advanced infection stage, one or more cup-shaped outgrowths called "enations" appear on the underside of the leaf.

Occurrence of CLCuD was first observed on cotton plants in Multan district of Punjab province during 1967 (Hussain and Ali, 1975). Before 1990's, there was consistent persistence of the disease without causing any significant damage. But in 1991, the disease appeared in 
epidemic form and in the subsequent years causing significant reduction in production from 12.82 million bales during 1991 to 8.04 million bales during 1994 . During the last decade this disease has caused a loss of 1.5 billion US dollars to national economy by the loss of 9.35 million bales of cotton (USDA, 2013).

The losses estimates for cotton production by this disease are still alarming in Pakistan after the appearance of new Burewala CLCuD strain, which caused a breakdown of resistance in the cotton varieties (Mahmood et al., 2003; Mansoor et al., 2003). Due to fruitless attempts for CLCuD resistant varieties, exploitation of plant traits minimizing the yield losses under disease pervasiveness is the best option to overcome the threat (Akhtar et al., 2003).

Seed cotton yield and fiber quality of cotton basically depends upon cotton boll. Cotton breeders, usually, focus on increasing number of bolls per unit area to increase the yield per unit land area (Coyle and Smith, 1997). Manipulations of plant variables responsible for seed cotton yield per boll have very little been investigated. These boll related traits synonymously known as withinboll yield components including number of seeds per boll, seed mass per boll, lint mass per boll, lint mass per seed, seed mass per seed etc. play a very basic role in determining the final seed cotton yield and fiber quality. Coyle and Smith (1997) reported that genotypes having positive general combining ability (GCA) effects for fiber quality exhibited negative GCA effects of various withinboll yield traits. Lint yield is largely contributed by boll number per unit area, seed number per boll and lint mass per seed (Worley et al., 1974). Seeds per boll, boll number per unit area and lint mass per seed are the important factors in enhancing cotton yield (Worley et al., 1974). Lint production can be increased by increasing the number of productive seeds, producing more lint fibers, hence increasing the surface area for increased lint production (Ali et al., 2015).

Predominance of non-additive genes for bolls per plant, boll weight and seed cotton yield was reported by Waldia et al. (1980) and Ahuja and Dhayal (2007), while Kumaresan et al. (1999) documented the predominance of both additive and dominance gene action for seed cotton yield and boll number. For seeds per boll, number of boll per plant, lint per seed, seed cotton yield and lint percentage, higher estimates of specific combining ability (SCA) variances than GCA were found (Imran et al., 2012). Tang and Xiao (2013) reported the predominance of additive variances for seed mass per seed and lint mass per seed while dominance gene action for seed number per boll and lint mass per boll.

During the last decade, intense work on development of cotton hybrids showed a discrete amount of increase in cotton production and to combat the biotic and abiotic stress factors. But still there is need to enhance efforts to find out genetically diverse lines with improved combining ability to develop hybrid oriented population which possesses wide adaptation, early maturity, high yield potential, tolerance to biotic and abiotic stress factors and, off-course, good fiber characteristics. For continuous genetic improvement of cotton, heterosis breeding is an important tool which can be further enhanced through the selection for combining ability analysis between diverse parents (Braden et al., 2003; Kumar, 2008). Therefore it is important to get detailed information about desired parental combiners reflecting high heterotic response for the exploitation of valuable hybrid combinations in any breeding program.

The objectives of current study were to evaluate the performance of the selected cotton varieties and their $F_{1}$ hybrids under CLCuD infested condition for various within-boll yield components and to estimate the range of heterotic potential of the hybrids for within-boll yield attributes under the stressed environment.

\section{MATERIALS AND METHODS}

Present research was conducted at experimental area of the Department of Plant Breeding and Genetics, University of Agriculture, Faisalabad, during the year 2012-13. Breeding material was developed by crossing six cultivars of cotton viz: FH-113, MNH-886, MNH-888, IR-4, VH-61 and FH-2015. These cultivars were grown under controlled condition in a glasshouse during October 2012. Electric and steam heaters were used to maintained the temperature at $28^{\circ} \pm 2^{\circ}$ and $60 \% \pm 5$ humidity at night while $35^{\circ} \pm 2$ and $40 \% \pm 5$ at day. Mercury vapor lamps were used to supplement day light during winter. At mature bud stage, all genotypes were crossed in complete $6 \times 6$ diallel matting design to produce $\mathrm{F}_{0}$ seed.

The harvested $F_{0}$ seeds from greenhouse were then planted in the field in randomized complete block design (RCBD); with three replications during June 2013, to produce $F_{1}$ progeny. Ten plants were planted in each row. Plant to plant and row to row distance were maintained at 30 and $75 \mathrm{~cm}$, respectively. High humidity due to rains aid in creating environment suitable for rapid growth of the virus. Weather data during the entire growth period of the cotton is shown in Figure 1.

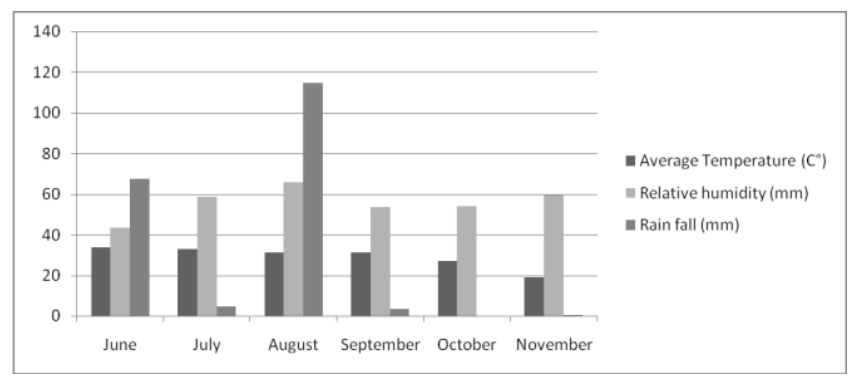

Figure 1. Weather conditions during the crop growth period (June to November 2012).

Data were recorded at maturity from five randomly selected plants from each row of three replications. 30 bolls sample was selected from each plot and weighed to measure seed cotton yield. These samples were ginned in laboratory to separate seed and lint fractions while rest of the measurements was done using following formulas: 
Lint percentage $(\mathrm{L} \%)=($ lint weight $/$ seed cotton weight) $\times 100$

Lint mass per boll $(\mathrm{LM} / \mathrm{B})=$ Lint weight of sample/No. of bolls in sample

Seed mass per boll $(\mathrm{SM} / \mathrm{B})=$ Seed weight of sample/No. of bolls in sample

Seed number per boll $(\mathrm{SN} / \mathrm{B})=$ Total No. of seeds in sample/No. of bolls in sample

Lint mass per seed $(\mathrm{LM} / \mathrm{S})=$ Lint mass per boll/seed number per boll

Seed mass per seed $(\mathrm{SM} / \mathrm{S})=$ Seed mass per boll/seed number per boll

CLCuD index $=($ Sum of all disease ratings of sampled plants/total number of plants $) \times(100 / 6)$

Within-boll yield components were calculated as reported by Tang and Xiao (2013) while CLCuD incidence $(\%)$ was determined by using the disease scale described by Akhtar et al. (2005).

The data of different traits from each replication were averaged and subjected to analysis of variance to determine the significant differences among genotypes for different within-boll yield components under study following Steel et al. (1997). Characters having significant differences were further analyzed for combining ability effects as described by Griffing Method-I, Model-I (1956). Heterosis over mid and better parent was determined as suggested by Fehr (1987).

\section{RESULTS}

Analysis of Variances showed highly significant differences among the parents and their crosses for all the studied traits, which indicated the presence of high variability in breeding material for the traits under contemplation (Table 1). Variances due to SCA were greater than variances due to GCA for all the traits indicating the presence of non-additive gene action except lint mass per boll which showed higher reciprocal effects i.e. presence of maternal effects. Prevalence of non additive factor of genetic control became more prominent by the ratio of $\sigma^{2} \mathrm{gca} / \sigma^{2} \mathrm{sca}$ which was less than unity. While degree of dominance $\left(\sigma^{2} \mathrm{D} / \sigma^{2} \mathrm{~A}\right)^{1 / 2}$ was more than unity which further inveterate the above results along with pointing to the presence of over dominance nature of genes governing all the traits.

Table 1. Analysis of variances and genetic variances for various within-boll yield traits in Gossypium hirsutum L.

\begin{tabular}{llllllllll}
\hline Source & d.f & $\mathbf{L} \%$ & LM/B & SM/B & SN/B & LM/S & SM/S & SCY & CLCuD \\
\hline Replications & 2 & $1.66^{\mathrm{NS}}$ & $0.02^{\mathrm{NS}}$ & $0.21^{* *}$ & $1.85^{\mathrm{NS}}$ & $0.000004^{\mathrm{NS}}$ & $0.000019^{\mathrm{NS}}$ & $19.78^{\mathrm{NS}}$ & $27.33^{\mathrm{NS}}$ \\
Genotypes & 35 & $98.21^{* *}$ & $0.21^{* *}$ & $0.13^{* *}$ & $45.98^{* *}$ & $0.000134^{* *}$ & $0.000108^{* *}$ & $760.98^{* *}$ & $306.66^{* *}$ \\
Error & 70 & 4.82 & 0.04 & 0.05 & 4.04 & 0.000006 & 0.000010 & 12.52 & 61.36 \\
GCA & 5 & $18.23^{* *}$ & $0.09^{* *}$ & $0.05^{* *}$ & $18.17^{* *}$ & $0.000065^{* *}$ & $0.000049^{* *}$ & $247.42^{* *}$ & $0.18^{* *}$ \\
SCA & 15 & $36.64^{* *}$ & $0.03^{*}$ & $0.05^{* *}$ & $11.73^{* *}$ & $0.000045^{* *}$ & $0.000035^{* *}$ & $257.16^{* *}$ & $0.07^{* *}$ \\
RCA & 15 & $33.67^{* *}$ & $0.11^{* *}$ & $0.03^{*}$ & $17.98^{* *}$ & $0.000038^{* *}$ & $0.000033^{* *}$ & $252.24^{* *}$ & $0.07^{* *}$ \\
Error & 70 & 1.61 & 0.01 & 0.02 & 1.35 & 0.000002 & 0.000003 & 4.17 & 0.05 \\
$\sigma^{2} \mathrm{gca}$ & 1.38 & 0.01 & 0.00 & 1.40 & 0.00001 & 0.000004 & 20.27 & 0.29 \\
$\sigma^{2} \mathrm{sca}$ & & 35.03 & 0.01 & 0.03 & 10.38 & 0.00004 & 0.000031 & 252.99 & 67.25 \\
$\sigma^{2} \mathrm{rca}$ & 16.03 & 0.05 & 0.01 & 8.32 & 0.00002 & 0.000015 & 124.03 & 61.19 \\
$\sigma^{2} \mathrm{~A}$ & 2.77 & 0.01 & 0.01 & 2.80 & 0.00001 & 0.00001 & 40.54 & 0.57 \\
$\sigma^{2} \mathrm{D}$ & 35.03 & 0.01 & 0.03 & 10.38 & 0.00004 & 0.00003 & 252.99 & 67.25 \\
$\sigma^{2} \mathrm{gca} / \sigma^{2} \mathrm{sca}$ & 0.04 & 0.46 & 0.10 & 0.13 & 0.12 & 0.12 & 0.08 & 0.00 \\
$\left(\sigma^{2} \mathrm{~A} / \sigma^{2} \mathrm{D}\right)^{1 / 2}$ & 0.28 & 0.96 & 0.44 & 0.52 & 0.49 & 0.49 & 0.40 & 0.09 \\
\hline
\end{tabular}

(**** and NS represents highly significant $(\mathrm{P}<0.01)$, significant $(\mathrm{P}<0.05)$ and non-significant differences respectively)

$(\mathrm{L} \%=$ lint percentage; $\mathrm{LM} / \mathrm{B}=$ lint mass per boll; $\mathrm{SM} / \mathrm{B}=$ seed mass per boll; SN/B = seed number per boll; LM/S = lint mass per seed; SM/S = seed mass per seed; $\mathrm{SCY}=$ seed cotton yield; $\mathrm{CLCuD}=$ cotton leaf curling disease index).

GCA effects relating to within-boll yield components showed that genotype MNH-886 proved to be the best general combiner for lint mass per boll seed mass per seed and CLCuD index; MNH-888 for lint mass per seed, seed cotton yield; VH-61 for seed mass per boll and seed number per boll and IR-4 for lint percentage (Table 2). All these parents showed highly significant $(\mathrm{P} \leq 0.01))$ and positive GCA effects for all the traits except seed mass per boll which showed significant $(\mathrm{P} \leq 0.05)$ and positive $\mathrm{GCA}$ effects.
Cross combinations which showed the best highly significant and positive SCA effects for various traits were: FH-113 $\times$ FH-2015 for lint mass per boll and seed number per boll; MNH-888 $\times$ IR-4 for lint percentage and lint mass per seed; MNH-888 $\times \mathrm{VH}-61$ for seed cotton yield and CLCuD index. Cross of FH-2015 with IR-4 andVH-61 exhibited significant but negative SCA effects of equal magnitude $(-0.22)$ for seed mass per boll, while rest of the crosses showed non-significant results for the trait. $\mathrm{MNH}-886 \times \mathrm{MNH}-888$ presented highest significant positive SCA effects for seed mass per seed (Table 3 ). 
Table 2. General Combining Ability (GCA) effects of parents for various within-boll yield parameters in Gossypium hirsutum L.

\begin{tabular}{lllllllll}
\hline Parents & L \% & LM/B & SM/B & SN/B & LM/S & SM/S & SCY & CLCuD \\
\hline FH-113 & $-0.4^{\mathrm{NS}}$ & $0.02^{\mathrm{NS}}$ & $0.07^{*}$ & $0.91^{* *}$ & $-0.001^{* *}$ & $0.0003^{\mathrm{NS}}$ & $4^{* *}$ & $0.30^{\mathrm{NS}}$ \\
MNH-886 & $0.68^{*}$ & $0.10^{* *}$ & $0.0^{\mathrm{NS}}$ & $-0.6^{\mathrm{NS}}$ & $0.0007^{\mathrm{NS}}$ & $0.0029^{* *}$ & $-1.7^{* *}$ & $-2.48^{* *}$ \\
MNH-888 & $0.87^{*}$ & $0.07^{*}$ & $-0.01^{\mathrm{NS}}$ & $0.92^{* *}$ & $0.0023^{* *}$ & $0.0005^{\mathrm{NS}}$ & $4.07^{* *}$ & $1.31^{* *}$ \\
IR-4 & $1.55^{* *}$ & $-0.03^{\mathrm{NS}}$ & $-0.10^{*}$ & $-1.8^{* *}$ & $0.0010^{* *}$ & $-0.003^{* *}$ & $-6.8^{* *}$ & $0.92^{* *}$ \\
VH-61 & $-1.2^{* *}$ & $-0.04^{\mathrm{NS}}$ & $0.08^{*}$ & $1.34^{* *}$ & $-0.004^{* *}$ & $-0.001^{*}$ & $3.5^{* *}$ & $-0.79^{* *}$ \\
FH-2015 & $-1.6^{* *}$ & $-0.13^{* *}$ & $-0.04^{\mathrm{NS}}$ & $-0.8^{* *}$ & $0.0012^{* *}$ & $0.0005^{\mathrm{NS}}$ & $-3.1^{* *}$ & $0.73^{* *}$ \\
SE (GCA) & 0.33 & 0.03 & 0.03 & 0.31 & 0.0004 & 0.0005 & 0.54 & 1.19 \\
\hline
\end{tabular}

For abbreviations, see legend to Table 1.

Table 3. Specific combining ability (SCA) effects of 15 F1 hybrids for various within-boll yield Parameters in Gossypium hirsutum L.

\begin{tabular}{|c|c|c|c|c|c|c|c|c|}
\hline Crosses & $\mathrm{L} \%$ & LM/B & SM/B & SN/B & LM/S & $\mathbf{S M} / \mathbf{S}$ & SCY & CLCuD \\
\hline FH-113 × MNH-886 & $-2.1 *$ & $-0.08^{\mathrm{NS}}$ & $-0.03^{\mathrm{NS}}$ & $-3.0 * *$ & $-0.0002^{\mathrm{NS}}$ & $0.001^{\mathrm{NS}}$ & $4.58 * *$ & $0.90^{\mathrm{NS}}$ \\
\hline FH-113 × MNH-888 & $-0.6^{\mathrm{NS}}$ & $-0.06^{\mathrm{NS}}$ & $0.10^{\mathrm{NS}}$ & $1.85^{\mathrm{NS}}$ & $-0.0028 *$ & $-0.005 * *$ & $-6.57 * *$ & $0.73^{\mathrm{NS}}$ \\
\hline FH-113 × IR-4 & $0.87^{\mathrm{NS}}$ & $0.08^{\mathrm{NS}}$ & $0.03^{\mathrm{NS}}$ & $-0.43^{\mathrm{NS}}$ & $0.0026^{*}$ & $-0.005 * *$ & $6.33^{* *}$ & $0.95^{\mathrm{NS}}$ \\
\hline FH-113 × VH-61 & $1.80^{\mathrm{NS}}$ & $-0.01^{\mathrm{NS}}$ & $0.05^{\mathrm{NS}}$ & $0.47^{\mathrm{NS}}$ & $-0.004 * *$ & $-0.001^{\mathrm{NS}}$ & $-12.0 * *$ & $1.11^{\mathrm{NS}}$ \\
\hline FH-113 × FH-2015 & $2.07 *$ & $0.20 *$ & $0.04^{\mathrm{NS}}$ & $4.83 * *$ & $-0.003 * *$ & $0.004 * *$ & $6.19 * *$ & $-8.69 * *$ \\
\hline MNH-886 × MNH-888 & $-0.2^{\mathrm{NS}}$ & $0.11^{\mathrm{NS}}$ & $-0.15^{\mathrm{NS}}$ & $0.36^{\mathrm{NS}}$ & $-0.004 * *$ & $0.007 * *$ & $-0.56^{\mathrm{NS}}$ & $3.23 * *$ \\
\hline MNH-886 × IR-4 & $-1.0^{\mathrm{NS}}$ & $-0.13^{\mathrm{NS}}$ & $0.17^{\mathrm{NS}}$ & $0.09^{\mathrm{NS}}$ & $-0.0006^{\mathrm{NS}}$ & $0.001^{\mathrm{NS}}$ & $-10.1 * *$ & $0.51^{\mathrm{NS}}$ \\
\hline MNH-886 × VH-61 & $-3.7 * *$ & $-0.05^{\mathrm{NS}}$ & $-0.05^{\mathrm{NS}}$ & $0.17^{\mathrm{NS}}$ & $0.0032 * *$ & $-0.004 * *$ & $-6.75 * *$ & $8.43 * *$ \\
\hline MNH-886 × FH-2015 & $-1.1^{\mathrm{NS}}$ & $0.09^{\mathrm{NS}}$ & $0.07^{\mathrm{NS}}$ & $-5.1 * *$ & $0.0057 * *$ & $0.004 *$ & $6.25^{* *}$ & $-5.39 * *$ \\
\hline MNH-888 × IR-4 & $7.1 * *$ & $0.13^{\mathrm{NS}}$ & $0.05^{\mathrm{NS}}$ & $-0.73^{\mathrm{NS}}$ & $0.0084 * *$ & $0.002^{\mathrm{NS}}$ & $-0.56^{\mathrm{NS}}$ & $-0.27^{\mathrm{NS}}$ \\
\hline MNH-888 × VH-61 & $-4.5 * *$ & $-0.06^{\mathrm{NS}}$ & $0.09^{\mathrm{NS}}$ & $-1.46^{\mathrm{NS}}$ & $-0.0023^{*}$ & $0.004 *$ & $28.55 * *$ & $-11.04 * *$ \\
\hline MNH-888 × FH-2015 & $0.06^{\mathrm{NS}}$ & $-0.02^{\mathrm{NS}}$ & $-0.11^{\mathrm{NS}}$ & $1.35^{\mathrm{NS}}$ & $0.0046^{* *}$ & $-0.003 *$ & $-14.4 * *$ & $11.29 * *$ \\
\hline IR-4 × VH-61 & $2.31 *$ & $0.09^{\mathrm{NS}}$ & $-0.14^{\mathrm{NS}}$ & $0.36^{\mathrm{NS}}$ & $-0.0019^{\mathrm{NS}}$ & $0.005^{* *}$ & $-5.16 * *$ & $-3.22 * *$ \\
\hline IR-4 × FH-2015 & $2.05 *$ & $-0.07^{\mathrm{NS}}$ & $-0.22 *$ & $-0.03^{\mathrm{NS}}$ & $-0.008 * *$ & $-0.002^{\mathrm{NS}}$ & $12.01 * *$ & $7.98 * *$ \\
\hline VH-61 × FH-2015 & $5.34 * *$ & $-0.01^{\mathrm{NS}}$ & $-0.22 *$ & $0.51^{\mathrm{NS}}$ & $0.0069 * *$ & $-0.004 *$ & $2.93^{\mathrm{NS}}$ & $3.92 * *$ \\
\hline S.E (SCA) & 1.06 & 0.1 & 0.1 & 0.97 & 0.0011 & 0.0015 & 1.7 & 3.77 \\
\hline
\end{tabular}

For abbreviations, see legend to Table 1.

Reciprocal effects showed that the hybrid MNH- $886 \times$ FH-113 for seed mass per boll and lint mass per seed; MNH-888 $\times$ MNH-886 for lint mass per boll and seed cotton yield. While for the disease index, FH-2015 $\times$ MNH-886 gave the superior results. For the traits like lint percentage, seed number per boll and seed mass per seed, the hybrids VH-61 $\times$ FH-113, VH-61 $\times$ IR-4 and IR-4 $\times$ MNH-888 exhibited the best reciprocal effects, respectively (Table 4).

Table 4. Reciprocal effects for $15 \mathrm{~F}_{1}$ hybrids for various within-boll yield Parameters in Gossypium hirsutum $\mathrm{L}$.

\begin{tabular}{|c|c|c|c|c|c|c|c|c|}
\hline Crosses & L \% & LM/B & SM/B & SN/B & $\mathbf{L M} / \mathbf{S}$ & SM/S & SCY & CLCuD \\
\hline MNH-886×FH-113 & $0.26^{\mathrm{NS}}$ & $0.28 * *$ & $0.26 * *$ & $2.45 * *$ & $0.0062 * *$ & $-0.003 * *$ & $4.21 * *$ & $12.45 * *$ \\
\hline MNH- $888 \times$ FH-113 & $-3.02 * *$ & $-0.23 * *$ & $0.11^{\mathrm{NS}}$ & $-1.55^{\mathrm{NS}}$ & $-0.005 * *$ & $0.0044 * *$ & $-8.0^{* *}$ & $-2.81 * *$ \\
\hline IR-4×FH-113 & $2.86^{* *}$ & $0.11^{\mathrm{NS}}$ & $0.00^{\mathrm{NS}}$ & $1.51^{\mathrm{NS}}$ & $0.0035 * *$ & $0.0003^{\mathrm{NS}}$ & $-18.00 * *$ & $4.24 * *$ \\
\hline VH-61×FH-113 & $5.73 * *$ & $0.08^{\mathrm{NS}}$ & $-0.20 *$ & $3.81 * *$ & $0.0021 * *$ & $-0.005 * *$ & $-17.14 * *$ & $15.83 * *$ \\
\hline FH-2015×FH-113 & $-0.41^{\mathrm{NS}}$ & $-0.25 * *$ & $-0.03^{\mathrm{NS}}$ & $-5.1 * *$ & $0.0003^{\mathrm{NS}}$ & $-0.0025^{\mathrm{NS}}$ & $-5.04 * *$ & $-12.45^{* *}$ \\
\hline MNH- $888 \times$ MNH- 886 & $3.54 * *$ & $0.70 * *$ & $-0.07^{\mathrm{NS}}$ & $2.93 * *$ & $-0.007 * *$ & $-0.009 * *$ & $19.16^{* *}$ & $-3.10 * *$ \\
\hline IR-4×MNH-886 & $4.37 * *$ & $0.09^{\mathrm{NS}}$ & $-0.06^{\mathrm{NS}}$ & $3.94 * *$ & $0.0011^{\mathrm{NS}}$ & $0.0038 * *$ & $-1.59^{\mathrm{NS}}$ & $0.83^{\mathrm{NS}}$ \\
\hline VH-61×MNH-886 & $5.39 * *$ & $-0.13^{\mathrm{NS}}$ & $-0.13^{\mathrm{NS}}$ & $-1.80 *$ & $0.0028 * *$ & $0.0007^{\mathrm{NS}}$ & $-5.26 * *$ & $-7.41 * *$ \\
\hline FH-2015×MNH-886 & $-3.53 * *$ & $0.11^{\mathrm{NS}}$ & $-0.19 *$ & $-0.71^{\mathrm{NS}}$ & $0.0027 * *$ & $0.0003^{\mathrm{NS}}$ & $-6.31 * *$ & $-12.87 * *$ \\
\hline IR-4×MNH-888 & $-9.90 * *$ & $-0.11^{\mathrm{NS}}$ & $0.09^{\mathrm{NS}}$ & $-0.37^{\mathrm{NS}}$ & $-0.009 * *$ & $0.0078 * *$ & $5.11 * *$ & $-9.08 * *$ \\
\hline VH-61×MNH-888 & $4.71 * *$ & $0.00^{\mathrm{NS}}$ & $-0.20 *$ & $-2.8 * *$ & $0.0035 * *$ & $-0.004 * *$ & $-21.75 * *$ & $-5.68 * *$ \\
\hline FH-2015×MNH-888 & $0.27^{\mathrm{NS}}$ & $0.00^{\mathrm{NS}}$ & $-0.05^{\mathrm{NS}}$ & $-3.0 * *$ & $0.0058 * *$ & $-0.0006^{\mathrm{NS}}$ & $-4.10 * *$ & $7.02 * *$ \\
\hline VH-61×IR-4 & $-0.38^{\mathrm{NS}}$ & $0.22 *$ & $0.08^{\mathrm{NS}}$ & $3.99 * *$ & $0.0025^{*}$ & $0.0034 *$ & $-0.06^{\mathrm{NS}}$ & $1.02^{\mathrm{NS}}$ \\
\hline FH-2015×IR-4 & $0.64^{\mathrm{NS}}$ & $-0.05^{\mathrm{NS}}$ & $0.05^{\mathrm{NS}}$ & $3.29 * *$ & $0.0009^{\mathrm{NS}}$ & $-0.0030 *$ & $-9.34 * *$ & $-9.38 * *$ \\
\hline FH-2015×VH-61 & $2.86 * *$ & $0.01^{\mathrm{NS}}$ & $0.13^{\mathrm{NS}}$ & $3.61 * *$ & $-0.0006^{\mathrm{NS}}$ & $0.0005^{\mathrm{NS}}$ & $-11.20 * *$ & $-0.93^{\mathrm{NS}}$ \\
\hline S.E (RCA) & 0.9 & 0.08 & 0.09 & 0.82 & 0.001 & 0.0013 & 1.44 & 3.2 \\
\hline
\end{tabular}

For abbreviations, see legend to Table 1. 
Some astonishing results were also revealed by some of the crosses. A parent having high GCA values when crossed with a parent showing poor GCA value yield hybrids with high SCA effects as for example FH-113 was good general combiner for seed number per boll while FH-2015 was poor combiner for the trait yet their combination produced desirable results for increasing number of seeds per boll. MNH-888 was found to be poor combiner for disease tolerance or we can say good combiner for increased disease infestation while VH-61 presented good GCA effects regarding disease tolerance, but they yielded hybrids with reduced disease infestation.

\section{Heterosis and Heterobeltiosis effects}

Heterosis and Heterobeltiosis effects were expressed as the increase or decrease, in percentage, over mid parent and better parent, respectively. Significant and positive mid parent heterosis was observed for lint percentage and seed cotton yield only while all the other traits showed non-significant mid parent (MP) heterosis (Table 5). The highest (average) MP heterosis was estimated for seed cotton yield $(17.63 \%)$ while the undesirable heterosis for the disease index (17.02\%) was observed. Average mid parent heterosis for lint percentage and lint mass per boll was recorded as $12.14 \%$ and $11.37 \%$, respectively.

Table 5. Heterotic effects over mid and better parent of 30 hybrids for various within-boll yield related traits in Gossypium hirsutum L.

\begin{tabular}{|c|c|c|c|c|c|c|c|c|}
\hline & \multicolumn{4}{|c|}{ МРH } & \multicolumn{4}{|c|}{ BPH } \\
\hline & Average & Range & $\mathbf{N}(+)$ & $\mathbf{N}(-)$ & Average & Range & $\mathbf{N}(+)$ & $\mathbf{N}(-)$ \\
\hline $\mathrm{L} \%$ & $12.14 *$ & -27.81 to 65.04 & $20(18)$ & $10(6)$ & $0.92^{\mathrm{NS}}$ & -36.62 to 48.62 & $14(8)$ & $16(9)$ \\
\hline LM/B & $11.37^{\mathrm{NS}}$ & -42.42 to 76.63 & $21(6)$ & $9(2)$ & $-2.30^{\mathrm{NS}}$ & -45.93 to 57.42 & $11(2)$ & $19(3)$ \\
\hline SM/B & $-7.43^{\mathrm{NS}}$ & -39.34 to 25.33 & $11(1)$ & $19(8)$ & $-13.8^{\mathrm{NS}}$ & -43.34 to 24.22 & $8(0)$ & $22(11)$ \\
\hline SN/B & $1.84^{\mathrm{NS}}$ & -31.55 to 69.23 & $14(9)$ & $16(7)$ & $-6.91^{\mathrm{NS}}$ & -41.49 to 58.37 & $11(5)$ & $19(12)$ \\
\hline $\mathbf{L M} / \mathbf{S}$ & $2.06^{\mathrm{NS}}$ & -20.01 to 37.86 & $17(9)$ & $13(8)$ & $-3.39^{\mathrm{NS}}$ & -31.03 to 36.79 & $12(6)$ & $18(11)$ \\
\hline SM/S & $1.07^{\mathrm{NS}}$ & -16.90 to 35.84 & $14(8)$ & $16(6)$ & $-3.08^{\mathrm{NS}}$ & -22.44 to 34.26 & $11(11)$ & $19(4)$ \\
\hline SCY & $17.63 *$ & -54.49 to 129.9 & $18(14)$ & $12(8)$ & $-0.91^{\mathrm{NS}}$ & -58.79 to 124.3 & $14(8)$ & $16(15)$ \\
\hline CLCuD & $17.02^{\mathrm{NS}}$ & -51.06 to 84.72 & $20(9)$ & $10(3)$ & $3.17^{\mathrm{NS}}$ & -59.74 to 69.33 & $16(4)$ & $14(4)$ \\
\hline
\end{tabular}

For abbreviations, see legend to Table 1 .

Most of the crosses had positive and significant MP heterosis for the above mentioned four characters. Hybrid VH-61 $\times$ MNH-888, IR-4 $\times$ MNH-888 and FH-2015 $\times$ FH-113 showed the maximum heterotic increase in seed cotton yield, lint percentage and lint mass per seed, respectively. An undesirable heterosis in the disease infestation was also observed in most of the crosses, however some hybrids also showed significant negative heterosis for the trait.

In terms of heterosis over better parent (BP), lint percentage and CLCuD index showed non-significant and positive BP heterosis while rest of all the traits showed non-significant negative BP heterosis (Table 5). Despite the absence of significant heterosis, CLCuD index, lint percentage, seed cotton yield and lint mass per seed showed the wider range of variation with respect to $\mathrm{BP}$ heterosis than the other traits for the 30 crosses. Most of the hybrids showed positive BP heterosis for CLCuD index, but minority of them showed significant BP heterosis while negative BP heterosis was observed for majority of 30 crosses for all the other traits.

\section{DISCUSSION}

Significant differences among the six parental genotypes and their crosses for within-boll yield components verified the existence of genetic unevenness for the concerned traits. Significant mean square values of parents versus hybrids for all the investigated traits indicated the existence of non-additive gene action and high heterotic responses for the traits. The lower value of $\sigma^{2} \mathrm{GCA} / \sigma^{2}$ SCA indicated a pre-dominance of nonadditive gene action in the inheritance of traits (Sprague and Tatum, 1942). Lint mass per boll was controlled by maternal effects due to high reciprocal effects while the rest of the traits exhibited non-additive gene action. Previous studies exposed that variation in seed cotton yield and within-boll yield traits were controlled by genes acting either non-additively (Coyle and Smith, 1997; Inam-Ul-Haq and Azhar, 2004; Neelima et al., 2004; Iqbal et al., 2005; Rahman et al., 2005, Ahuja and Dhayal, 2007; Basal et al., 2009; Imran et al., 2012; Tang and Xiao, 2013) or additively (Green and Culp, 1990; Liu and Han, 1998; Ahmad et al., 2001). Present results confirmed non-additive genetic control for all the studied traits. Contradictory results could result from the cultivars having different genetic backgrounds or environmental conditions during growth.

Higher values of $\sigma^{2} \mathrm{D}$ over $\sigma^{2} \mathrm{~A}$ suggested the preponderance of dominant genetic effects for all traits except lint mass per boll which strongly suggested later generation selection or heterosis breeding for improvement in these traits while for the exceptional trait, repeated selection should be made from earlier generations for genetic gain in the character (Basal et al, 2009; Tang and Xiao, 2013).

General combining ability effects are equivalent to additive effects, which are important genetic information to find out the desirable general combiner for improving traits of interest (Wu et al., 2010). The parental genotypes like MNH-888 for lint mass per seed and seed cotton yield; MNH-886 for lint mass per boll, seed mass per seed and CLCuD index; while VH-61 for seed mass per boll and seed number per boll could be put forth to produce 
desirable combinations regarding better GCA effects for improvement in the respective traits.

Specific combining ability is the performance of any two parental genotypes in a particular combination for a particular trait. It is generally expected that parental genotypes having good general combining ability perform well when they come together in a cross combination and produce best performing hybrids as reported by (Irfanullah et al., 1994; Haq and Azhar, 2005). From the results of current study it can be drawn that the hybrids MNH- $888 \times$ IR-4, FH-113 $\times$ FH-2015 and MNH-888 with VH-61 can be used in future breeding programs aimed at improvement in lint percentage and lint mass per seed, lint mass per boll and seed number per boll, seed cotton yield and CLCuD resistance, respectively.

Sometime among the parental genotypes in a cross combination one parent has poor general combining ability while second one contains good general combining ability were producing the best specific combining ability hybrid (Shakeel et al. 2001; Basal and Turgut 2003; Mondal and Hossain, 2006). The results indicated that a higher GCA does not necessarily confer a higher SCA and that the GCA and SCA were independent of one another as reported by Khan et al. (2007) and Khan et al. (2009). Similar case was found in recent study that FH-113 had poor general combining ability all the traits but its crosses like FH-113 $\times$ FH-2015 showed the best specific combining ability for lint mass per boll while IR-4 $\times$ MNH-888 showed best reciprocal effects for seed cotton yield. Similar results were also observed by Baloch and Chang (1970); Azhar and Rana (1993).

Among reciprocal hybrids, combination of MNH-886 and FH-113 showed best reciprocal effects for seed mass per boll and lint mass per seed while $\mathrm{MNH}-888 \times \mathrm{MNH}-$ 886 gave the highest reciprocal effects lint mass per boll and seed cotton yield. FH-2015 $\times$ MNH-886 showed best reciprocal effects for CLCuD index. These results will be helpful while selecting these genotypes as male or female parents in hybridization program for the mentioned traits.

Theoretically if the heterozygous dominant cross showed greater results than mean of homozygous parents then positive mid-parent heterosis would expected otherwise negative mid-parent heterosis would expected (Wu et al., 2010). In current study, only seed cotton yield and Lint percentage showed the average highest, positive and significant mid-parent heterosis i.e. $17.63 \%$ and $12.14 \%$, respectively while rest of all the traits showed non-significant results. However, none of the trait showed significant better parent heterosis. The majority of the crosses produced higher mid parent and better parent values for investigated traits.

Generally, crosses with higher heterosis values have either a positive SCA or high mean performance. But in some cases it can be concluded that the parents possessing only high values need not necessarily produce high yielding hybrids as indicated by the present study for the traits like seed mass per boll and CLCuD index (Kumar, 2008). Hybrid VH-61 $\times$ MNH-888 showed maximum heterosis over mid parent for seed cotton yield and IR-4 $\times$ MNH-888 for lint percentage and lint mass per seed (data not shown). Meredith and Brown (1998) found $1.4 \%$ average mid parent heterosis for lint percentage in $F_{2}$ progeny. Same results were also found in the previous findings of Basal et al. (2009); Tang and Xiao (2013). The utilization of heterosis for certain characters in some of these crosses is possible for commercial exploitation.

Although, results of present study are in accordance with most of previous researchers but also incompatible with many others. These differences in phenotypic expression from other scientists may be due to different type of genetic materials tested under different climatic and soil conditions. Thus based upon this information, the present material may be used advantageously for exploiting heterosis in the characters through the development of hybrid seed.

\section{CONCLUSION}

In present genetic investigation, analysis of variance showed that all the genotypes differed significantly from each other for all traits. All the traits were significantly governed by non-additive type of gene action which restricts for selection in early generations and suggesting the adoption of heterosis breeding. Among parents MNH888, MNH886, IR-4, VH-61 and showed the significant GCA results for most of the within-boll yield traits while among crosses, MNH-888 $\times$ VH-61, IR-4 $\times$ FH-2015 and MNH- $888 \times$ IR- 4 were proved as the promising hybrids. Two hybrids FH-2015 $\times$ IR-4 and IR-4 × MNH-888 showed the highest mid parent heterosis and better parent heterosis for most of the within-boll yield components, respectively. The combination of these two parents and their cross with other parents can be used to exploit the within-boll yield parameters of cotton under CLCuD pervasiveness.

\section{LITERATURE CITED}

Ahmad, I., A. Ali, M. Zubair and I.A. Khan. 2001. Mode of gene action controlling seed cotton yield and various components in Gossypium hirsutum L. Pak. J. Agric. Sci. 38:19-21.

Ahuja, S.L. and L.S. Dhayal. 2007. Combining ability estimates for yield and fiber quality traits in $4 \times 13$ line $\times$ tester crosses of Gossypium hirsutum. Euphytica 153:87-98.

Akhtar, K.P., A.I. Khan, M. Hussain, M.A. Haq, and M.S.I. Khan. 2003. Upland cotton varietal response to cotton leaf curl virus (CLCuV). Trop. Agric. Res. Ext. 5:29-34.

Akhtar, K.P., M. Aslam, M. Ahsan-ul-Haq, F.F. Jamil, I. Khan and M.T. Elahi. 2005. Resistance to Cotton Leaf Curl Virus $(\mathrm{CLCuV})$ in a Mutant Cotton Line. J. Cotton Sci. 9:175-181.

Akhtar, K.P., M.A. Haq, M. Hussain and A.I. Khan. 2002. Whitefly transmitted Gemini viruses and associated disorders in cotton: A Review. Pak. J. Phyto. 14:140-150

Ali, I., A. Shakeel, A.A. Khan and B. Sadia. 2015. Genetic basis of variation for within- boll yield components in cotton. Turk. J. Agri. For. DOI: 10.3906/tar-1409-117.

Anonymous, 2012-13. Pakistan Economic Survey, Govt. of Pakistan, Ministry of Finance, Economic Advisor's Wing, Islamabad.

Azhar, F.M. and A.H. Rana. 1993. Genetic analysis of some quantitative plant characters in upland cotton. Pak. J. Agri. Sci. 30:89-93. 
Baloch, M.A.A. and M.A.K. Chang. 1970. Preliminary investigation on the combining ability in $(G$. hirsutum L.) number of bolls per plant. West Pak. J. Agri. Res. 8:157-167.

Basal, H. and I. Turgut. 2003. Heterosis and combining ability for yield components and fiber quality parameters in a half diallel cotton (G. hirsutum L.) Population. Turk. J. Agri. For 27:207-212.

Basal, H., A. Unay, O. Canavar and I. Yavas. 2009. Combining ability for fiber quality parameters and within-boll yield components in intraspecific and interspecific cotton populations. Spanish J. Agri. Res. 7:364-374.

Braden, C., C.W. Smith, P. Thaxton. 2003. Combining ability for near extra long fibers in Upland cotton. Beltwide cotton conference. January 6-10, Nashville.

Coyle, G.G. and C.W. Smith. 1997. Combining ability for within-boll yield component in cotton, G. hirsutum L. Crop Sci. 37:1118-1122.

Farooq, A., J. Farooq, A. Mahmood, A. Batool, A. Rehman, A. Shakeel, M. Riaz, M.T.H. Shahid, S. Mehboob. 2011. An overview of cotton leaf curl virus disease (CLCuD) a serious threat to cotton productivity. Aust. J. Crop Sci. 5:1823-1831.

Fehr, W.R. 1987. Principles of cultivar development. Theory and techniques. Macmillan Publishing Company Inc. New York. 115-119.

Green, C.C. and T.W. Culp. 1990. Simultaneous improvement of yield, fiber quality, and yarn strength in upland cotton. Crop Sci. 30:66-69.

Griffing, B. 1956. Concept of general combining ability and specific combining ability in relation to diallel crossing system. Aust. J. Biol. Sci. 9:463-493.

Hameed, S., S. Khalid, E.Haq and A.A. Hashmi. 1994. Cotton leaf curl disease in Pakistan caused by a whitefly transmitted gemini virus. Plant. Dis. 78:529.

Haq, M.I. and F.M. Azhar. 2005. Genetic analysis of some agronomic characters in upland cotton. Int. J. Agri. Biol. 14:283-8.

Hussain, T. and M. Ali. 1975. A Review of Cotton Diseases of Pakistan. The Pak. Cotton 19:71-86.

Imran, M., A. Shakeel, F.M. Azhar, J. Farooq, M.F. Saleem, A. Saeed, W. Nazeer, M. Riaz, M. Naeem and A. Javaid. 2012. Combining ability analysis for within-boll yield components in upland cotton (Gossypium hirsutum L.). Genet. Mol. Res. 11:2790-2800.

Inam-ul-Haq and F.M. Azhar. 2004. Genetic basis of varietal differences for seed cotton yield and its components in hirsutum spp. Int. J. Agri. Biol. 6:904-907.

Iqbal, K., F.M. Azhar, I.A. Khan and Ehsan-Ullah. 2011. Variability for drought tolerance in cotton (Gossypium hirsutum) and its genetic basis. Int. J. Agri. Biol. 13:61-66.

Iqbal, M., R.S.A. Khan, K. Hayat and N.I. Khan. 2005. Genetic variation and combining ability for yield and fiber traits among cotton $F_{1}$ hybrid population. J. Biol. Sci. 6:678-683.

Irfanullah, M., A. Khan, H.A. Sadaqat and A.A. Khan. 1994. Potentials of combining ability for yield and lint quality traits in cotton (Gossypium hirsutum L.). J. AgriRes. 32:363367.

Khan, N.U., G. Hassan, K.B. Marwat, M.B. Farhatullah. 2009. Diallel analysis of some quantitative traits in Gossypium hirsutum L. Pak. J. Bot. 41:3009-3022.

Khan, N.U., G. Hassan, M.B. Kumbhar, A. Parveen, U. Aiman, W. Ahmad, S.A. Shah and S. Ahmad. 2007. Gene action of seed traits and oil content in upland cotton (G. hirsutum L.). Sabrao J. Breed Genet. 39:17-30.

Kumar, K.J.Y. 2008. Combining ability and heterosis studies in experimental hybrids of cotton (Gossypium hirsutum L.) MSc. Thesis, Dept. of Genetics and Plant Breed. College of Agric. Dharwad Univ. of Agric. Sci.
Kumaresan, D., P. Senthilkumar and J. Ganesan. 1999. Combining ability studies for quantitative traits in cotton (Gossypium hirsutum L.). Madras Agri. J. 18:430-432.

Liu, Y.X. and X.M. Han. 1998. Research on combining ability and inheritance of 12 economic characters in upland cotton. China Cotton 25:9-11.

Mahmood, T., M. Arshad, M.I. Gill, H.T. Mahmood and M.T. Hussain. 2003. Burewala strain of cotton leaf curl virus: A threat to CLCuV cotton resistant varieties. Asian J. PlantSci. 2:968-970.

Mansoor, S., I. Amin, S. Iram, M. Hussain, Y. Zafar, K.A. Malik and R.W. Briddon. 2003. The breakdown of resistance in cotton to cotton leaf curl virus disease in Pakistan. New Dis. Rep. 7.

Mansoor, S., I. Bedford, M.S. Pinner, J. Stanley and P.G. Markham. 1993. A whitefly transmitted geminivirus associated with cotton leaf curl diseases in Pakistan. Pak. J. Bot. 25:105-107.

Meredith, W.R. and J.S. Brown. 1998. Heterosis and combining ability of cottons originating from different regions of the United States. J. Cotton Sci. 2:77-84.

Mondal, M.A.A. and M.M. Hossain. 2006. Combining ability in potato (Solanum tubersum L.). Bangladesh J. Bot. 35:125131.

Neelima, S., V.C. Reddy and A.N. Reedy. 2004. Combining ability studies for yield and yield components in American cotton (G. hirsutum L.). Ann. Agri. Biol. Res. 9:1-6.

Rahman, H., S.A. Malik and M. Saleem. 2005. Inheritance of seed physical traits in upland cotton under different temperature regimes. Spanish J. Agri Res. 3:225-232.

Shakeel, A., I.A. Khan and F.M. Azhar. 2001. Study pertaining to the estimation of gene action controlling yield and related traits in upland cotton. J. Biol Sci. 1:67-70.

Sprague, G.F. and L.A. Tatum. 1942. General vs. specific combining ability in single crosses of corn. Agron. J. 34:923932.

Steel, R.G.D. and J.H. Torrie. 1997. Principles and procedures of statistics: A biometrical Approach. $2^{\text {nd }}$ Ed. Mcgraw hill book Co., Inc., New York.

Tang, F. and W. Xiao. 2013. Genetic effects and heterosis of within-boll yield components in upland cotton (Gossypium hirsutum L.). Euphytica 194:41-51.

USDA. 2013. Foreign Agriculture Service. Global Agricultural Information Network. GAIN Report No. PK1302. Washington, DC, USA.

Waldia, R.S., B.R. More and D.S. Jatasra. 1980. Line $\times$ tester analysis for yield and economic attributes in Gossypium hirsutum L. Indian J. Agri Sci. 50:745-747.

Worley, S., T.W. Culp and D.C. Harrell. 1974. The relative contributions of yield components to lint yield of upland cotton, Gossypium hirsutum L. Euphytica 23:399-403.

Wu, J., J.C. McCarty, J.N. Jenkins and W. R. Meredith. 2010. Breeding potential of introgressions into upland cotton: genetic effects and heterosis. Int. J. Plant Breed. 129:526-53.

Yassin, A.M. and E. El-Nour. 1970. Transmission of cotton leaf curl virus by single insect of Bemisia tabaci. Plant Dis. Rept. 54:528-531. 